\title{
COMMUNITY ENTERPRISE: WHAT TYPE OF ENTERPRISE FOR WHAT TYPE OF COMMUNITY?
}

\author{
Martin Perry \\ New Zealand Institute for Social Research and Development
}

\begin{abstract}
Optimism is spreading in many communities that businesses owned and controlled by local people can generate jobs for the unemployed and provide valuable services. Perhaps the best known example is the whale watch enterprise in Kaikoura, which is one of over 20 community businesses promoted by the Ngai Tahu Trust Board. Across the country, many other community-controlled businesses have appeared. In Westport, the Buller Community Fertiliser Company is processing waste from the local cement works into fertiliser. The Kaitaia Community Business and Environment Centre is engaged on a landfill and recycling project to serve 10,000 residents. The Tuapeka-Lawrence Community Company is renovating the Lawrence Museum, adding an information centre and planning to promote other tourist ventures.
\end{abstract}

There is a long history of community enterprise in the Maori community that might be looked to for experience. But the recent outburst in activity has been government led and looked overseas for guidance. Late in its life, the last Labour government hastily introduced several measures to stimulate community-based economic initiatives which drew on overseas' experience, especially that from Scotland, to guide local action.

In Scotland a range of different types of community enterprise can be found, including community businesses, community cooperatives and community credit unions. Community businesses have been by far the most visible and in New Zealand advocates of community enterprise have argued that they provide a model for regenerating economically depressed communities.

This paper examines Scottish experience, especially its community economic initiatives through the establishment of the Community Employment Group. Local authorities are also increasingly involved in promoting local economic initiatives. This activity has grown because of the urgent need to respond to rising unemployment but unless there is a clearer understanding of the types of initiatives that will work, well-intentioned efforts will be wasted. Much activity has been based on a mistaken impression of Scottish experience and especially the supposed success of community business. Moreover as we explain below, New Zealand is a less favourable for community business than Scotland. Community cooperatives and the community credit unions may well be better examples to build on. Before explaining these arguments, some discussion of the recent growth of community enterprise in New Zealand is needed.

\section{Local Economic Initiatives in New Zealand}

The employment promotion measures introduced by the last Labour government fell into two main areas (sec Perry. 1990,1991 for details). The Competitive Business and Employment Growth programme focused on suppor to conventional small firms. The centrepiece of this programme was the opening of the national network of Business Development Centres under the control of the Ministry of Commerce. The second arm of the strategy was under the control of the Department of Labour and directed support to community-based employment initiatives. Two important measures in this programme were the Local Employment and Enterprise Scheme (LEEDS) and the opening of the Community Employment Development Unit (CEDU).

LEEDS gave grants to support the establishment of resource centres to promote community-based economic initiatives. There are now over 50 LEEDS-supported centres distributed throughout the country, many of which are involved in community business ventures. Subsequently, CEDU was established as an independent unit in the Department of Labour to provide strategic guidance on the development of community-based economic initiatives. It also gave grants to 'trailblazer' ventures identified as models for other groups to follows. Both programmes have continued following reviews last year. CEDU is now the Community Employment Group (CEG) with additional responsibility for a number of programmes formerly controlled by the Department of Internal Affairs and the Department of Labour.

CEDU's first director, Peter Kenyon, gave particular attention to helping community businesses. This endorsement followed a visit by two community business practitioners from Scotland who had previously worked in a Glasgow-based community business development unit. Their visit, sponsored by the Department of Internal Affairs, spread the message that community businesses were working in Scotland and could work here (Hyndman and Roxburgh, 1990). They left a model of how community businesses could be organised which was promoted by CEDU (Employment Matters, 1990a) and advocated by many of the LEEDS-funded resource centres, one of 
which published a manual on community businesses (Manawatu Resource Centre, 1990).

The BullerCommunity Development Company (BCDC) is an example of the way these measures came together and how local communities were encouraged to use the community business model. The BCDC came about following a visit to Westport by the two Scottish consultants in 1989. A local enterprise initiative in Westport had been proposed soon after the Lane Walker Rudkin and PDL factory closures in 1987. A consultant, paid for by the Christchurch branch of the NZ Engineering Union and a local accountant proposed that a development trust be established to help redundant workers pursue self employment options. This idea came too early to benefit from the Labour government's initiatives and failed to get off the ground. The desire to do something lingered and when the apparent success of community businesses in Scotland was learned about, a group of local activists seized on this model. CEDU also backed the idea and in 1990 the BCDC was established using a LEEDS grant to support running costs and a 'trailblazer' grant to fund feasibility studies. The first community business commenced operation early last year converting the byproduct of the local cement works into fertiliser. The business has taken on two unemployed people and there is optimism that this could grow to over 10.

So far so good, but BCDC's directors acknowledge that it has been a qualified success. The goal was to build community-based businesses. In reality BCDC exists through the commitment of a few activists. Local residents and businesses were invited to become members of the company and encouragingly around 135 (mainly individuals) joined but it has been difficult to extend their commitment beyond the membership fee of a few dollars. Part of the problem is that identifying gaps in the local economy for a community business has proved harder than anticipated and while progress is slow, community interest wanes. Efforts to establish a business based on local forestry resources or waste recycling have yet to identify any commercial possibilities open to a community business. The fertiliser business was a one-off opportunity arising from the collapse of the original operation. Meanwhile the goal of becoming a self supporting business is along way off. Government grants continue to be the main source of running costs and investment funds.

The problems are not unique to BCDC. Since the visit by the Scottish consultants, the "honeymoon period' for community business in Scotland has ended. Over the last few years, a number of established community businesses have collapsed, including what was once the largest (Barrowfield Community Business) with debts of several million dollars. This is one of the reasons why, in New Zealand, it is also necessary to take a closer look at the community business model before advocating continued promotion.

\section{Community Business in Scotland}

In Scotland there are now over 150 community businesses, most of which were set up during the 1980s. As a form of community enterprise the community businesses are distinctive in three main ways.

First, the organisational structure comprises three tiers of control. Ultimate control rests with the members of the company who elect a board of directors and set the goals and objectives for the company. The directors carry the main responsibility for running the company, although they do not draw any income from the business as all profits are for the use of the company. Day to day management and administration is provided by paid employees, providing the third tier in the business.

Second, the process of building a community business puts the initial emphasis on establishing a holding company. Actual operations come later and operate as subsidiary companies of the building company.

Third, the business claims its community association by opening membership of the company to any individual or group within their community (usually defined as a particular locality but it could mean a social group such as young unemployed, ex-offenders or the disabled). To encourage membership, low subscription fees are favoured which means that the business must supplement these resources to obtain its running costs and investment funds. In addition, community businesses pursue social as well as economic goals. This usually involves giving priority to the long-term unemployed in the allocation of jobs and offering support services to help unemployed persons pursuing their own self-employment ideas.

A round estimate is that the 150 community businesses employ 1,000 workers. A further 2,000 people work in other enterprises which rent workspace from community businesses or are temporary trainees. The number of jobless in Scotland was recently around 350,000. Clearly, these initiatives do not offer even a partial solution to unemployment. However they operate in some of the most economically deprived locations and often have as their main objective the provision of jobs to long term unemployed.

Run down industrial environments and large municipal housing estates are the typical locations of Scotland's community businesses. Over half of the businesses are found in and around the city of Glasgow where the traditional industrial base of shipbuilding and heavy engineering has all but disappeared over the last 20 years. Although urban locations give access to a wide labour market community businesses have succeeded in their goal of providing jobs for unemployed local people. Over $80 \%$ of the workers in urban community businesses are drawn from the immediate vicinity and $85 \%$ of the jobs have gone to the previously unemployed or those supported by temporary job creation and training schemes. Perhaps 
even more impressive is that around half of all recruits had been unemployed for over a year. This penetration into the ranks of the unemployed and long term unemployed is a major difference between community enterprise and private sector small businesses.

Ferguslie Park Community Holdings is a good example of the successes and difficulties a community business can experience. Ferguslie Park is a public housing estate with 15,000 residents in Paisley, a town close to Glasgow. Unemployment is over $20 \%$, housing conditions rank amongst the worst in Europe, the local service base comprises a scattering of comer shop units only a few of which are occupied. Low incomes and stigma make such estates no-go areas for private investment, while low car ownership and few public transport links make it difficult to travel to other parts of the city for work. These problems can be found in many of Scotland's peripheral housing estates.

Through an urban aid grant from central and local government, which helped prepare the premises and paid the wages of a manager, Ferguslie Park residents established their first community business in the early 1980s. This business employed five workers in a stone cleaning service specialising in the removal of graffiti from public buildings. The business grew in the mid 1980s when a major environmental improvement programme for the estate was launched. The community business tendered successfully for building and security work associated with the regeneration scheme. at its peak almost 100 local residents worked for the business with many having long histories of unemployment. The workforce has since reduced but the business remains the largest employer of local people in the neighbourhood. However, despite a brief period of viability the enterprise has struggled commercially. These difficulties have meant that the public agencies involved have had to extend grant aid for longer than originally anticipated and more recently they have intervened and placed a number of their own representatives on the community business's board.

Like the Buller story therefore success has been qualified. In some respects what success the business has had is despite the characteristics of the community business model rather than because of them. There has been little community involvement in the running of the business and it had to rely mainly on a few committed local individuals acting in a voluntary capacity. This is part of the reason why the grant authorities insisted on supplementing the community business board. The lack of community support also extends to the workers. Some people may expect extra commitment from the employees, but workers tend to see the business the same as any other job even though it may be their only realistic prospect of work. Furthermore, finding and keeping managers with the appropriate blend of commercial skills and community activism has also created difficulties. The business has had several managers making any planning difficult.
The message from Scotland therefore is that community businesses have the potential to make a marginal but important contribution to promoting employment in hardhit communities. However, their successes cannot simply be put down to their community-based and democratic attributes. Two conditions have helped to foster community businesses in Scotland: (1) local market opportunities; and (2) public funding support. It is doubtful whether either of these influences will be as supportive in New Zealand as becomes clear when each is considered.

\section{Local Market Opportunities}

Popular activities for Scottish community businesses are environmental and construction-related work, neighbourhood security patrols, providing small workspaces and local shops. The market for these services is usually the immediate community, such as a large public sector housing estate where there is often little by way of an existing local economy. The scale of these estates and the problems they give rise to has no parallel in New Zealand.

Furthermore, many community businesses, like the one in Ferguslie Park, have been able to tap into work generated by government efforts to regenerate these areas. Over the last 10 years there has been a strong tradition of areafocused regeneration which has sought to improve the environment of older urban areas and depressed housing estates. In this context, community businesses have attracted a share of the work involved. Much of this is also the kind of work that demands unskilled labour which, in turn, has made it easier for community businesses to fulfil their objective to giving jobs to the long term unemployed. This goal would have been harder to achieve if community businesses were operating in higher level activities which demand a more skilled workforce.

New Zealand's community businesses will have to search for different market opportunities, especially if they are to avoid competing with existing local services - less a problem in Scotland because of the lack of services where community businesses operate. Without a clear and ready market base the structure of a community business can also become a burden. A danger is that the cart is put before the horse; effort being spent building up an organisational structure while the search for viable business opportunities receives secondary attention. In Scotland, many community businesses operate with top heavy administrative structures more equivalent to a medium-sized enterprise than other small firms with which they compete.

\section{Public Sector Funding}

Public sector finance has been an essential ingredient in the growth of community businesses. Since the 1970 s numerous government programmes have supplied grants to groups working to regenerate inner city environments. The Urban Aid Programme, which provides capital and revenue grants, has been critical in getting community 
businesses up and running: 9 out of 10 of Scotland's community businesses would not have started without this grant aid (McGregor, McArthur and Noone, 1987) and many would be unable to survive without it (McArthur and McGregor, 1990). In addition, many community businesses have derived income by managing various training and temporary work schemes that are funded by government. Although a small number of businesses have graduated beyond reliance on these direct sources of grant aid, most remain dependent on public subsidy. Indeed, there are little grounds for optimism that Scotland's community businesses will, as things stand, emerge as a strong and free standing 'third sector' of the economy.

The public sector is also important as a major source of demand for the services that community businesses provide. Particularly in areas where govemment agencies are striving to regenerate the economy and the environment, this has provided a 'soft' market for some community businesses. In some cases they have been given favourable treatment which incorporates a hidden subsidy in contract pricing procedures.

Of course grant aid and subsidy is not necessarily a bad thing. A community business may not be profitable in a conventional accounting sense, but it could be operating as efficiently as it can while also providing valuable social benefits such as much needed local service or jobs for people who would not otherwise have one. A good case could be argued for ongoing subsidy for some 'non viable' enterprises. However this would probably require a major shift in the methods of assessment used by funding agencies and the adoption of methods which audit both economic and social contributions. However the advocates of social auditing have yet to convince those with their hands on the purse strings in Scotland that this concept of account is valid.

\section{Alternative Models of Community Enterprise}

The discussion so far has highlighted two main messages. Community businesses have an impressive record of creating jobs for disadvantaged workers in hard-hit communities but have been less successful in commercial terms, requiring heavy public subsidy. As a model of community enterprise, community business has several potential limitations: it relies heavily on outside resources, there is a tendency to concentrate on organisational structures rather than identifying viable business activities and, despite the ethos of community control, the involvement of local people has been limited. With these weaknesses in mind, policy makers and community activists in New Zealand should consider alternatives. From Scottish experience there may be more to be gained from promoting community cooperatives and community credit unions.

\section{Community Cooperatives}

Community cooperatives in Scotland are concentrated in isolated rural and island communities. They differ from community businesses by depending to a greater extent on financial contributions from their members to supply their capital base. To achieve this cooperatives must first identify projects addressing a shared need in the community and then mobilise finance from residents in the form of shares. The result is that they have succeeded in creating more community participation in the venture than most community businesses. Since the late 1970 s almost $\$ 1$ million has been raised in 20 communities and given that over half have populations of fewer than 500 , this is a substantial contribution. Government grants have nonetheless also been vital to the success of cooperatives. The Highlands and Islands Development Board (recently renamed Highland and Islands Enterprise), an agency of central government charged with the economic and social regeneration of the region, has matched the funds raised by communities dollar for dollar and provided grants to cover a manager's salary in the same way as does urban aid for community business.

The community cooperative model is not unfamiliar to New Zealand activists. CEDU sponsored a visit by Iain Clark from the Association of Community Enterprises in the Highlands and Islands of Scotland who explained Scotland's experience with community cooperatives (see Employment Matters, 1990b). Clark's message emphasised the importance of government financial support to cornmunity cooperatives which perhaps explains why the specific model was not taken up. However the matching grant scheme means that local communities are called on to make a financial contribution. This creates both a pool of working capital and creates a better chance of building a sense of local ownership and of 'locking in' community support.

A limitation and strength of the cooperative model is that the need for community-wide support means that they work best in small isolated locations where residents' attachments are strong and a clear local need is recognised. Many of the more successful cooperatives are found on small islands whose viability has been threatened by population decline and the loss of local services. In these areas the local community cooperative has often intervened to keep a vital service running. The changing population profile of rural Scotland has helped in this respect. While depopulation has been the dominant trend there has been selective new settlement by 'white settlers': typically professionals escaping the urban 'rat race' in preference for distance working. The new settlers bring skills, money and a desire to integrate into the community. Helping to build a cooperative has been a particularly suitable outlet for their resources and aspirations. 


\section{Community Credit Unions}

In contrast community credit unions are growing rapidly throughout Scotland. Credit unions are well established in New Zealand, but they do not have the close links to local neighbourhoods that is the distinguishing feature of a community credit union. Community credit unions accept share deposits and recycle these in the form of loans to members residing in their local community. Transactions are often modest. In the Scottish unions loans over $\$ 500$ are unusual and most are much smaller. Nonetheless, for those whole only other source of credit would be a high interest finance company or money lender the credit union can make a substantial improvement in their circumstances. In some cases it may even retain the capacity to work, for example when a loan pays a car repair bill.

Compared with the other models of community enterprise, credit unions offer two further advantages: (1) they are especially effective in bringing large numbers of local people together and retaining their participation. All community credit unions in Scotland are run by volunteers and none have paid managers; (2) they operate without large public subsidies and rely primarily on the funds collected from their members.

The community credit union is a largely unexplored model in New Zealand, which is perhaps surprising in view of the familiarity with other types of credit union. It is a model that warrants more attention. CEDU and its LEEDS-funded resource centres, on the other hand, have put more effort into promoting 'green dollar' schemes based on the barter exchange of goods and services in place of payment by money. This type of scheme has little potential to affect the circumstances of poor people. Basic necessities are hard to supply in barter systems and, or course, the unskilled jobless have little to barter.

\section{Conclusions}

Community enterprise in Scotland remains small scale and it will never be a solution to unemployment or the failure of the private sector. Nonetheless the answer to the first question set at the outset is that community-based economic initiatives do have the capacity to generate viable jobs. In Scotland community economic initiatives have demonstrated an ability to promote employment in the most disadvantaged locations for the long term unemployed. To use the language of policy analysts, community enterprises target their intended client groups more effectively and efficiently than programmes such as self employment subsidies or support to conventional small firms. However, the survival of community enterprise is in question. Only a minority of Scotland's community enterprises have made the transition into fully commercial ventures.

The context for local economic initiatives in New Zealand is more hostile than it has been in Scotland. Here they can expect much less financial support from government and they must search harder for work without the opportunities that have existed in Scotland's deprived public housing estates. The additional difficulties of getting established place greater reliance on the willingness of members to play an active voluntary role. It is often not difficult to attract support when projects are new and optimism is high, but sustaining participation over the long term is a battle. So too is attracting members with commercial ability. For these reasons the answer to our second question is that community businesses may not be the best model in many circumstances. Community cooperatives and community credit unions, which seem better able to mobilise local communities, should be given priority.

Finally, what action should be taken by government? First, financial support to community economic initiatives should be continued. It is evident that without public resources community-based economic initiatives have little chance of taking root. Such expenditure can be justified in terms of the growing need for initiatives to promote economic activity and generate employment. Closer inspection of the impacts of community enterprise, possibly through introducing social audits, may well highlight important contributions that may be missed in a narrow assessment of commercial performance. bit is also clear that govemment programmes need more thoughtful design, and this highlights the need for a unit such as CEG to guide local economic strategy. Most importantly the Group should become attuned to local constraints and possibilities. Too much wasted effort has resulted from the inappropriate advocacy of models developed in other environments. Initiatives seen from a distance may appear exciting, seductive and easy to copy, but in closer view a more selective adoption is often called for.

\section{Future Research}

There are a number of research initiatives which can be taken. These might start with an inventory of initiatives that are taking place including their funding sources, organisation, major activities and achievements. It would also be instructive to assess the activities being undertaken in light of overseas experience and to consider the potential advantages in transferring initiatives from one setting to another. There would be advantages in identifying best practices andconsidering possible public support for them.

\section{References}

Employment Matters 1990a Community-owned enterprise: saving jobs and services Project Profile Community Employment Development Unit, Wellington.

Employment Matters 1990b Community enterprise: Iain Clark in NZ Employment Matters Vol 1 No 4 
Community Employment Development Unit, Wellington.

Hyndman, V and Roxburgh, C 1989 Community business in New Zealand Department of Intemal Affairs, Wellington.

McGregor, A; McArthur, A \& Noone, V 1987 An evaluation of community business in Scotland Scottish Office, Edinburgh.

McArthur, A \& McGregor, A 1990 Communityenterprise in Scotland Occasional Paper 2 Training and EmploymentResearch Unit University of Glasgow.

Perry, M 1990 Local economic initiatives - What role for government? Public Sector 13: 4-8.

Perry, M 1991 The 1990small business package: a mirage masquerading as an economic strategy New Zealand Geographer 47:80-84. 